\title{
Patient Safety Movement in the Hospital and Public Health Center
}

\author{
Hanny Handiyani, S.Kp., M.Kep ${ }^{1}$, Dr. Rr. Tutik Sri Hariyati, S.Kp., Mars., Ns. \\ Agustin Indracahyani, S.Kep. \\ 1(Department of Basic Science Nursing, Faculty of Nursing, the University of Indonesia, Indonesia) \\ 2(Department of Basic Science Nursing, Faculty of Nursing, the University of Indonesia, Indonesia)
}

\begin{abstract}
Hospitals and public health care center are fraught with hazards, which may threaten patient safety. Thus, patient safety movement in the hospital and public health center are critical to be performed as a promotion to enhance the awareness of patient safety as well as a prevention of the incident of patient safety. The program which was conducted in 2012 aimed to improve visitors' behavior in safety in the Fatmawati General Hospital and Beji Primary Health Center that eventually may increase the degree of community health quality. This program consisted of reassessment (Focus Group Discussion), observation, giving questionnaire to workers and visitors in the hospital and public health care), planning, implementation (providing education and warning media, books titled "Safe in Hospital and Public Health Center", physical facilities, and socializing patient safety movement in the hospital and public health center), and evaluation. This activity reached an agreement on the action plan to continue the patient safety movement in their institutions. This activity could be a model for other hospitals and public health care centers, which have not yet implemented patient safety program.
\end{abstract}

Keywords-hazard, hospital, nurses, patient safety, public health center.

\section{Introduction}

Hazards in hospitals and public health care centers may endanger people's life. Those hazards could be physical (fall and radiation exposure), chemicals, ergonomics, biological or infections, and psychosocial problems, such as stress and anxiety. Physical hazards also include slipping on the bathroom or stair and electricity shock. Meanwhile, biological hazards include healthcare-acquired infections caused by microorganisms in the hospital and public health center. The mechanism of infections transmission involves behavior performed by patients and visitors, such as eating while the cleaner works, eating without hand washing, leaning on the elevator, sitting on the patients' room area and even sitting on the floor. These conditions also presented in the area of the hospital and public health care center that became the partner of this community outreach program.

Fatmawati General Hospital is a type A general hospital which becomes the main referral hospital for community in the South Jakarta and the surrounding areas. Many patients come every day to both inpatient and outpatient units. Bed Occupation Rate (BOR) of the inpatient unit is around $80-85 \%$. On the other hand, around 500 patients per day occupy the outpatient unit. The hospital is mainly accessed by lower class people $(51.4 \%$ of total bed is engaged by class III patients). The hospital nowadays tries to enhance its quality of services. One of them is by forming the committee of quality improvement and patient safety and committee of infection prevention and control. These efforts should be surely supported by the community.

Beji Public Health Center is one of three public health centers in the region level, or one of 32 health care centers in the city level. This health care center operates every Monday- Saturday (08.00-13.00WIB) and has around 20 workers. The services focus on the primary services. Health promotion and prevention are done by education and providing educational media. Curative programs are accomplished by treating the wide range of health problems, including HIV/ AIDS and tuberculoses. Rehabilitation is given through homecare to those who are referred from the hospital. Beji public health center makes an effort to improve its quality by following ISO accreditation. Furthermore, the public health center understands the necessity of patient safety and opens to positive changes for patient satisfaction through safety program.

The problems faced by the partners were the efforts to increase knowledge and understanding of the visitors regarding hazards in the hospital and public health center, enhance the obedience of visitors related to visiting regulations, utilize the effective media to encourage the visitors to participate in patient safety program as well as to educate them. In addition, both partners expected the workers to actively participate and contribute in the patient safety program. 
This program aimed to enhance behavior of safety in the hospital and public health center for patients and family or visitors, which may eventually give a positive impact to the improvement of health degree of community, especially in the South Jakarta and Depok. The specific objectives of this program were:

1.1 To deeply identify the most common safety problems of patients and families

1.2 To generate pocket books regarding safety in the hospital and public health center

1.3 To socialize the pocket books through the patient safety movement in the hospital and public health center

\section{Methods}

The program was accomplished by using various methods. The strategies were advocacy, social support, and empowerment of hospital and public health center societies. These approaches were relevant with the recommendation of WHO concerning global health promotion strategy (Notoatmodjo, 2010).

Advocacy was performed through focus group discussion with the representatives of Fatmawati General Hospital and Beji Public Health Center. The representatives of Fatmawati General Hospital were the Head of Nursing Committee and nurses, while the representatives of Beji Public Health Center were the Head of Public Health Center and healthcare workers in Beji Public Health Center. Social support was gathered by doing approach to the managers of the hospital and public health center along with socializing patient safety movement. Empowerment to nurses and healthcare workers was done by conducting workshop, education competition, hand washing demonstration to patients and other educational programs to retain patient safety from any hazards in the hospital and public health center.

Solutions offered to the partners included assessment of safety issues in the Fatmawati General Hospital and Beji Public Health Center, production of books titled "safe in the hospital and public health center" which based on the assessment result, making education and warning media, publication of educational and warning media installation of safety facilities in rooms and bathrooms, socialization of patient safety movement which consisted of workshop and competition, evaluation also action plan with leaders and workers of the Fatmawati General Hospital and Beji public health center.

\section{Result and Discussion}

This community outreach generally achieved the expected outcomes. This program has made the hospital and public health center implemented patient safety program.

The results of assessment were used as a reference to write the books and create educational and warning media. The results were as follow:

3.1 Focus Group Discussion (FGD)

The purpose of this activity focused on facilitating partners to:

3.1.1 Identify their needs on the improvement of patient safety

3.1.2 Determine the suitable instruments to identify safety issues on each institution

3.1.3 Identify the efforts that have been made by the partners to address safety issues

3.1.4 Identify efforts that have been done to improve patient safety

\subsection{Observation}

Observation was done to identify safety problems in the hospital and public health center. Scopes of observation were physical facilities and services provided to the patients.

3.3 Questionnaire
3.3.1
Patient

Image 1. Number of Patient's Companions ( $\mathrm{n}=29)$

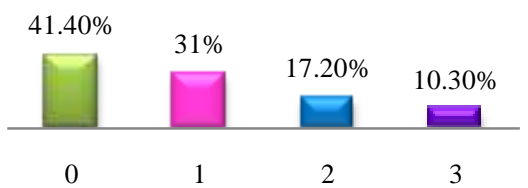

Image 1 demonstrates that the majority of patients came to the hospital/ public health center with companions $(58.6 \%)$, that are one person $(31 \%)$, two persons $(17.2 \%)$ and three persons $(10.3 \%)$. 
Image 2. Distribution of Patients' Health Problems $(n=29)$

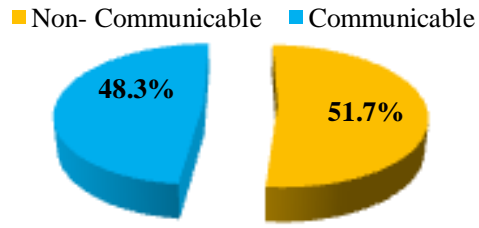

Image 2 shows that there is a slight difference on proportion of patient with non communicable (51.7\%) and communicable diseases $(48.3 \%)$.

Image 3. Level of Knowledge and Perception of Patients $(n=29)$

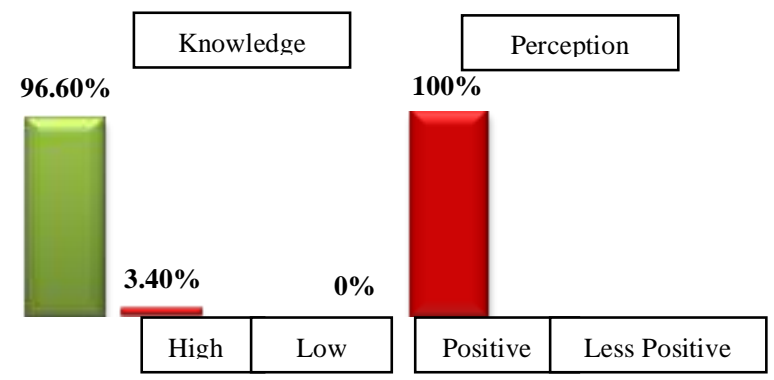

Image 3 proves that all patients have less-positive perception on safety (100\%) even though the majority of them have a high knowledge (96.6\%).

\subsubsection{Healthcare workers}

Table 1. Common Safety Problems

\begin{tabular}{lcc}
\hline \multicolumn{1}{c}{ Problems } & Fatmawati & \multicolumn{2}{c}{ Beji Public } \\
& General Hospital & Health Center \\
& $(\%)$ & 31.0 \\
\hline Way Finding & 28.0 & 31.0 \\
\hline Long line & 33.9 & 10.3 \\
\hline Unfriendly officers & 6.8 & 10.3 \\
\hline Unresponsive officers & 10.2 & 17.2 \\
\hline Littering & 11.0 & 0 \\
\hline Tardy doctors & 5.1 & 0 \\
\hline $\begin{array}{l}\text { Inadequacy of knowledge of officers to give patient's } \\
\text { education }\end{array}$ & 3.4 & 0 \\
\hline Complicated bureaucracy for assurance patients & 0.8 & 0 \\
\hline Sleep on the floor & 0.8 & 0 \\
\hline
\end{tabular}

Table 1 shows that longline is the major problem in Fatmawati General Hosptial (33.9\%) and Beji Public Health Center (31.0\%). Besides, wayfinding (31.0\%) is a main problem in Beji Public Health Center too.

Table 2. Safety Problems based on Visitors' Habits

\begin{tabular}{lcc}
\hline \multicolumn{1}{c}{ Problems } & $\begin{array}{c}\text { Fatmawati General } \\
\text { Hospital }(\%)\end{array}$ & $\begin{array}{c}\text { Beji Public Health } \\
\text { Center (\%) }\end{array}$ \\
\hline Not flushing the toilet & 36.2 & 9.1 \\
\hline Spitting & 23.2 & 27.3 \\
\hline Smoking & 21.7 & 31.8 \\
\hline Littering & 10.1 & 4.5 \\
\hline Coughing & 1.4 & 0.0 \\
\hline Bringing >2 relatives/ families & 4.3 & 0.0 \\
\hline Bringing children <10 years old & 1.4 & 0.0 \\
\hline Sleep on the waiting room's chair & 1.4 & 0.0 \\
\hline Disobedience & 0 & 27.3 \\
\hline
\end{tabular}

Based on the table 2., the majority of visitors in the Fatmawati General Hospital were not flushing the toilet (36.2\%), while majority of visitors in Beji Public Health Center were smoking (31.8\%). 
Table 3. Unsafe Conditions in the Hospital and Public Health Center

\begin{tabular}{lcc}
\hline \multicolumn{1}{c}{ Problems } & $\begin{array}{c}\text { Fatmawati } \\
\text { General } \\
\text { Hospital }(\%)\end{array}$ & $\begin{array}{c}\text { Beji Public } \\
\text { Health Center } \\
(\%)\end{array}$ \\
\hline No handrail in the bathroom & 3.2 & 5.9 \\
\hline $\begin{array}{l}\text { Transfer devices were limited and did not meet the } \\
\text { standards of safety }\end{array}$ & 3.2 & 0 \\
\hline Leaflet of patient safety were not distributed evenly & 1.6 & 0 \\
\hline Uneven floor & 1.6 & 0 \\
\hline Off elevator & 30.6 & 0 \\
\hline Geriatric patients were not accompanied and did not use & 6.5 & 0 \\
wheelchair & 1.6 & 0 \\
\hline Fire accident & 12.9 & 0 \\
\hline ACs were out of order & 1.6 & 0 \\
\hline Theft & 12.9 & 41.2 \\
\hline Slippery floor & 1.6 & 17.6 \\
\hline Impatience patients & 3.2 & 0 \\
\hline HAI & 1.6 & 0 \\
\hline B3 Chemicals & 1.6 & 0 \\
\hline Cardiac problems & 3.2 & 0 \\
\hline Waiting for doctor & 3.2 & 0 \\
\hline Children were not watched by parents & 8.1 & 0 \\
\hline Uncovered cable & 1.6 & 29.4 \\
\hline Patients fall & 0 & \\
\hline Insufficient space and facilities & & 0 \\
\hline
\end{tabular}

Table 3. demonstrates that the majority of unsafe conditions were elevators that were out of order in the Fatmawati General Hospital (30\%), and patients that did not want to queue patiently in Beji Public Health Center (41.2\%).

Several educational and warning media about patient safety had been revealed in strategic areas. Warning in sticker, poster, and banner have also been attached in walls so that patients could aware about biological, physical, and psychosocial safety.

Warning on physical hazards was put on certain different places in the hospital and public health center. Handrails and warning has also been installed on the side of staircase and in the bathrooms. Besides, warning about wet and slippery floor was put to make people aware and prevent the accident.

Biological safety from infections was promoted through the installation of sink, shower jet in the toilet, and fluid soap containers. Furthermore, warning media concerning hand washing methods have been attached on the wall of the sink or bathroom. This effort is relevant with what was cited by Craven \& Hirnle, 2003 that infections, which occur when microorganisms enter the body and grow, may be caused by dirty hands. Warning media about throwing trash on the appropriate can and procedures to wear mask have also been revealed. This is aimed to break the chain of infection (Smeltzer \& Bare, 1996).

Breaking the chain of infection is essential to prevent the transmission of infection from hospitals and public health centers to the society, which is known as healthcare acquired infections (HAI). HAI may occur during services in the hospital or other healthcare providers, with neither infections history nor in the incubation period prior to the services. These could be transmitted to both patients and healthcare workers.

Warning media have attractive and patient friendly designs which were beneficial for psychosocial safety. The attachment of media was followed by socialization to nurses and other healthcare workers to be friendly and use therapeutic communication during contact with patients and visitors in the hospital and public health center.

This community outreach program reached an action plan to continue the patient safety program which would be initiated and managed by the Head of nursing committee in the Fatmawati General Hospital and the Head of Beji Public Health Center. Other results of this community outreach program were adequate infrastructure and facilities that safe for patients and attributed with warning signs.

This program was in compliance with the program of committee of quality improvement and patient safety as well as committee of infection prevention control of Fatmawati General hospital. This program was also in accordance with the mission of both Fatmawati General Hospital and Beji Pubic Health Center which put quality in the front of services. Nowadays, HAI control becomes the indicator of hospital quality and one of the accreditation standards (Committee of Infection Prevention Control, 1999).

The evaluation of this program could be seen from the pretest dan posttest of the workshop with the following analysis: 
Table 4. knowledge of Public Health Center's Workers

\begin{tabular}{cccccccc}
\hline Level of Knowledge & Mean & SD & SE & Min- Max & $95 \%$ CI & t & P \\
\hline $\begin{array}{c}\text { Before the } \\
\text { intervention }\end{array}$ & 17.2 & 1.9 & 0.5 & $14-20$ & $16.15-18.25$ & 4.404 & 0.001 \\
\hline After the intervention & 19.1 & 0.8 & 0.2 & $17-20$ & $18.63-19.5$ & & \\
\hline & 1.87 & & & & & & \\
\hline
\end{tabular}

Table 4 shows that there was a significant difference between the level of knowledge of the public health center workers before and after the intervention. It means that this program has improved the knowledge of the public health center's workers.

The evaluation of this program could also be seen from the benefits felt by the partner, opinion, suggestion and recommendation given to this program. The results are as follow:

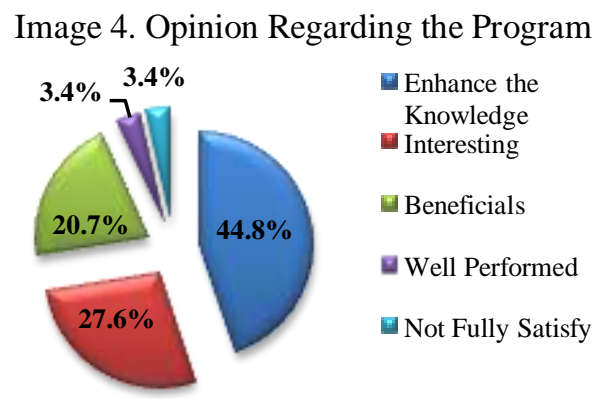

Image 4 demonstrates that the majority of healthcare workers in the hospital and public health center have broader knowledge on safety after participating on the patient safety movement (44.8\%).

Image 5. Benefits for partner

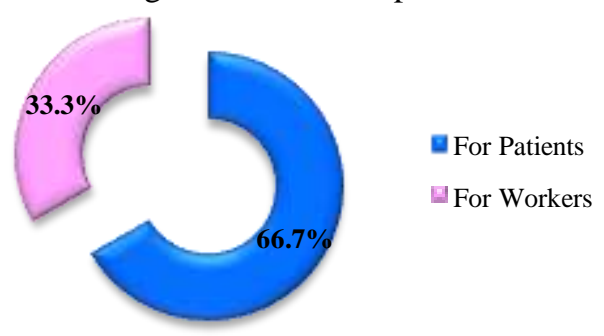

Image 5.illustrates that patients derived majority of benefits from the patient safety program (66.7\%).

Image. 6. Suggestion and Recommendations

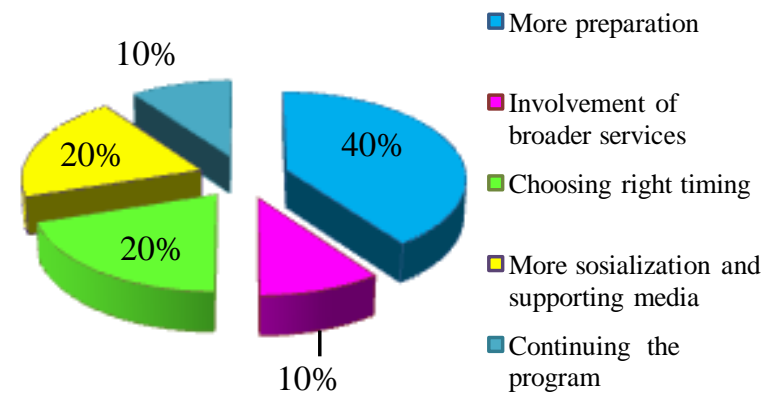

Image. 6 shows that most of the respondents suggested that the program should be more prepared (45\%). 
Both Fatmawati General ospital and Beji Public Health center as the partners of this community outreach program have actively involved in the program. They also have contributed on providing adequate supporting facilities for the successful of the program.

Due to the necessity of patient safety in the hospital and public health center, both Fatmawati General Hospital and Beji Public Health Center expected the continuity and sustainability of the program. Therefore, beased on discussion, both partners would become the pioneers or agents that lead patient safety program on their areas.

\section{Conclusion}

Safety problems in hospitals and public health centers could be prevented. An effort to keep patient safety is in accordance with the program of quality improvement and patient safety that have been started in the Fatmawati General Hospital and Beji Public Health Center through the Patient safety Movement.

This movement consisted of the attachment of educational and warning media in strategic areas, installation of safety facilities, provision of books titled safe in the hospital and public health center, and socialization of patient safety movement through workshop and competition. The evaluation on December 2012 showed that whole objectives of the program have been well achieved.

This program is expected to be continued in order to assure patient safety in the hospital and public health center. Books titled "Safe in the hospital and public health center" that have been written by the community outreach team were provided to help nurses in educating patients and visitors in the hospital and public health center. Media could also become guidance and support for nurses and patients to keep themselves safe from any hazards.

\section{Acknowledgements}

We would like to extend our gratitude to our students, Hilda Meriyandah and Dwanti Retno Asih for their assistance. We are also immensely grateful to Directorate Research and Community Outreach, which provided a generous grant year 2011-2012, along with Faculty of Nursing the University of Indonesia which provided continued supports. Finally, we thank Fatmawati General Hospital and Beji Public Health Center for their active contribution in this community outreach.

\section{References}

[1] R.E. Moore, Interval analysis (Englewood Cliffs, NJ: Prentice-Hall, 1966).

[2] Craven \& Hirnle, Fundamentals of Nursing: Human health and function. Fourth edition. (Philadelphia: Lippincott Williams \& Wilkins, 2003).

[3] Notoatmodjo, S., Promosi kesehatan: Teori dan aplikasi (Jakarta: Penerbit Rineka Cipta, 2010).

[4] Smeltzer.Sc. \& Bare B.G., Brunner \& Suddarth's textbook of medical surgical nursing. ( $\left.{ }^{\text {th }} \mathrm{ed}\right)$.

(Philadelphia: Lippincott Raven Publishers, 1996).

[5] Kemenkes RI, Pedoman pencegahan dan pengendalian infeksi di rumah sakit dan fasilitas pelayanan kesehatan lainnya (Jakarta: Kemenkes, 2011). 